\title{
The propeptide of cathepsin D increases proliferation, invasion and metastasis of breast cancer cells
}

\author{
SUJATA SARASWAT OHRI ${ }^{*}$, ARUNA VASHISHTA $^{1 *}$, MARY PROCTOR $^{2}$, \\ MARTIN FUSEK $^{3}$ and VACLAV VETVICKA ${ }^{1}$ \\ ${ }^{1}$ Department of Pathology, University of Louisville; ${ }^{2}$ Research Resource Center, University of Louisville, \\ and VA Medical Center, Louisville, KY 40202, USA; ${ }^{3}$ Institute of Organic Chemistry \\ and Biochemistry, Czech Academy of Science, Prague, Czech Republic
}

Received August 27, 2007; Accepted October 18, 2007

\begin{abstract}
Expression and secretion of procathepsin D (pCD) increases proliferation, metastasis and progression of breast cancer but the structural moiety by which $\mathrm{pCD}$ exerts these effects is still ambiguous. Here, we present data on a series of pCD stable mutants to identify the pCD region that mediates this mitogenic effect. Mutations affecting the region of the activation peptide (AP) were studied together with catalytic and glycosylation mutants. Mitogenic effect was evaluated using in vitro invasion and proliferation assays and in vivo by determining the tumorigenic potential. The catalytic mutants and glycosylation mutants of pCD continued to display enhanced cell proliferation, invasion and tumorigenicity similar to stable transfectants of native pCD, suggesting that neither the proteolytic activity nor the sugar moieties contribute to the mitogenic effect. However, stable transfectants of pCD lacking its AP and with various mutations in the 27-44 amino acid region of AP, failed to show enhanced cell proliferation or invasion in vitro and tumor growth in vivo, establishing the importance of AP region. Our study concludes that the entire 27-44 amino acid region of AP is necessary for the stimulatory actions of $\mathrm{pCD}$ on breast cancer cells.
\end{abstract}

\section{Introduction}

Proteins secreted by cancer cells are particularly useful as diagnostic and prognostic tumor markers and thus can be

Correspondence to: Dr Vaclav Vetvicka, Department of Pathology, University of Louisville, Louisville, KY-40202, USA

E-mail:vaclav.vetvicka@louisville.edu

${ }^{*}$ Contributed equally

Abbreviations: AA, amino acid; AP, activation peptide; $\mathrm{CD}$, cathepsin D; M6P, mannose-6-phosphate; $\mathrm{pCD}$, procathepsin D

Key words: activation peptide, breast cancer, invasion, procathepsin D, proliferation developed as targets for therapeutic interventions $(1,2)$. Among these proteins, proteases belonging to cathepsin family (L, B and D) are overexpressed and secreted by cancer cells in their proform with implications in cancer progression (3-5).

Procathepsin D (pCD), the proform of lysosomal aspartic peptidase cathepsin $\mathrm{D}(\mathrm{CD})$ is overexpressed and secreted by various cancer cell lines (6). Independent clinical studies have shown that its overexpression is correlated with an increased risk of clinical metastasis and short survival in breast cancer (7-9). Using the monoclonal antibody specific for the proform, it was shown that the pCD levels increase in plasma of patients with metastatic breast carcinoma (10). In normal physiological conditions, $\mathrm{pCD}$ is sorted to the lysosomes as mature $\mathrm{CD}$ and participates in intracellular protein catabolism, processing of antigens, hormones and neuropeptides $(11,12)$ and in apoptosis $(13)$. However, under cancerous conditions, $\mathrm{pCD}$ is overexpressed and its subsequent secretion affects multiple stages of tumor progression including proliferation $(14,15)$, angiogenesis (16) and metastasis (17). The role of $\mathrm{pCD}$ was further confirmed when downregulation of pCD expression by antisense gene transfer (18), ribozymes (19) and short hairpin RNA (20) significantly inhibited tumor growth in vivo. While, the role of $\mathrm{pCD}$ in cancer progression is well established, the molecular mechanism by which pCD exerts the mitogenic effect on cancer cells remains elusive.

The pCD is synthesized on the endoplasmic reticulum as a pre-pro-enzyme. After removal of signal peptide and attachment of sugars at its two N-linked glycosylation sites, the resultant pro-form $(52 \mathrm{kDa})$ is transported to Golgi stacks where it binds to mannose-6-phosphate (M6P) residues and is targeted to lysosomes (21). In the lysosomes, pCD is activated at low $\mathrm{pH}$ into an active intermediate form (48 kDa), by removal of its 44-amino-acid-long propeptide or activation peptide (AP). The intermediate form is then cleaved into a mature two-chain form CD (14 and $34 \mathrm{kDa}$ ) (22).

Our earlier studies, using the synthetic AP suggested that the mitogenic activity of pCD is through its AP that interacts with an unknown cell surface receptor present on cancer cells (23). In addition, recently we showed that the treatment of ZR-75-1 cells with synthetic AP resulted in induction of genes involved in signal transduction, cell cycle regulation, apoptosis, tumor invasion and metastasis (24). In the present 
study, we tested all the possible structural and functional features of pCD that could contribute to its growth-promoting effect. Wild-type and various mutant constructs of $\mathrm{pCD}$ were stably transfected in breast cancer cell lines, HBL-100 and MDA-MB-231, and examined using in vitro and in vivo studies. Our data establishes the role of AP in mediating the mitogenic activity of $\mathrm{pCD}$.

\section{Materials and methods}

Animals. Athymic nu/nu and normal BALB/c female mice were purchased from the Jackson Laboratory (Bar Harbor, $\mathrm{ME}$ ). Animal experiments were carried out with the approval of IACUC Committee and were in compliance with the regulations of the University of Louisville Animal Care.

Generation of constructs. The 1.1-kb human pCD cDNA (25) and the $\mathrm{pCD}(\triangle \mathrm{AP})$ cDNA (lacking the 44-amino acid coding sequence for the AP region) (26), were subcloned in the p3xFlag-CMV-14 (Sigma) vector at the BglII and XbaI sites. The mutant clones were constructed by amplifying the plasmid p3xFlag-CMVpCD using synthetic oligonucleotides (Invitrogen Life Technologies, Carlsbad, CA) and Site-directed Mutagenesis kit (Stratagene, La Jolla, CA). For generation of catalytic mutants, synthetic oligonucleotides comprised of an AAC codon (asparagine) instead of a GAC codon (aspartic acid) to mutate the Asp 33 and Asp 231 residues of pCD. Monoglycosylated and non-glycosylated pCD mutants were made by altering the codons for asparagine residues (N) at positions 70 and 199 to aspartic acid (D) with the corresponding synthetic oligonucleotides. The authenticity of incorporated mutations and cloned sequences was verified by DNA sequencing.

Cell lines and transfection. Breast cancer cell lines MDAMB-231, MCF-7, HBL-100 and ZR-75-1 were obtained from ATCC. The cancer cell lines were cultured in normal growth media consisting of RPMI with $10 \%$ fetal calf serum at $37^{\circ} \mathrm{C}$ in $5 \% \mathrm{CO}_{2}$ incubator. Cell lines were transfected at $70-80 \%$ confluency with $0.8 \mu \mathrm{g}$ of plasmid DNA mixed with $2.5 \mu \mathrm{l}$ of Lipofectamine 2000 (Invitrogen) reagent in Optimem-I media (Invitrogen) for $5 \mathrm{~h}$. The transfection medium was replaced with normal growth medium and $24 \mathrm{~h}$ later, G418 $(800 \mu \mathrm{g} / \mathrm{ml})$ was added to select for stably transfected cells for 2-3 weeks. The single stable transfectants were isolated by limited dilution method in 96-well plates and expanded further.

Western blot analysis. Stably transfected cells $\left(2 \times 10^{5}\right)$ were seeded in 24-well plate in normal growth media for $24 \mathrm{~h}$. The media was changed to RPMI containing $0.1 \%$ FCS and the cells were allowed to grow for another $48 \mathrm{~h}$. The supernatants were collected, concentrated (10X) using centrikon (Pall Life Sciences, Ann Arbor, MI) and quantified using BCA assay kit (Pierce, Rockford, IL). Ten micrograms of total proteins were diluted in Laemmli sample buffer and heated at $95^{\circ} \mathrm{C}$ for $5 \mathrm{~min}$. Electrophoresis of the denatured samples and Western blotting was performed as previously described (27). The primary antibodies employed in this study were Anti-Flag M2 (Sigma) and Anti-AP (23). Anti-mouse IgG-alkaline phosphatase conjugate (Sigma) was used as secondary antibody. pCD-antibody complexes were detected using NBT-BCIP alkaline phosphatase substrate kit (Bio-Rad).

Proteolytic activity assay. Cells $\left(2 \times 10^{5}\right.$ cells $\left./ \mathrm{ml}\right)$ were seeded in normal growth medium. After $24 \mathrm{~h}$, the media was changed to RPMI with $0.1 \%$ FCS and the cells were incubated for another $48 \mathrm{~h}$. Conditioned media was collected, concentrated (10X) and tested for the proteolytic activity. In brief, total proteins $(100 \mu \mathrm{g})$ were incubated at $37^{\circ} \mathrm{C}$ with hemoglobin (Sigma) in sodium acetate buffer $\mathrm{pH} 3.6$ (1.1-ml, final volume) in the absence or presence of $2 \mathrm{mM}$ Pepstatin A (Sigma) for $20 \mathrm{~h}$. The proteolytic activity was calculated from the TCA-soluble hemoglobin by measuring absorbance at $280 \mathrm{~nm}$.

In vitro invasion analysis. For evaluation of the invasion across Matrigel layers, a commercial kit manufactured by Chemicon International (Temecula, CA, USA) was used according to the manufacturer's instructions. Briefly, cells $\left(3 \times 10^{5}\right)$ were added to each well and placed in the incubator for $48 \mathrm{~h}$. Cells that migrated through the matrix and became attached to the other side of the insert were fixed, stained and quantitated by dissolving the stained cells in $10 \%$ acetic acid. An aliquot of stained cells was transferred to a 96-well plate for colorimetric reading at $560 \mathrm{~nm}$.

Purification of pCD and mutant proteins. Control and mutant pCD transfectants of HBL-100 were grown in Cell Max (Spectrum Labs, Rancho Dominguez, CA). The expressed and secreted protein was purified from the supernatants collected over time, using anti-Flag M2 affinity gel (Sigma) chromatography. The Flag-fused proteins were bound to anti-Flag M2 column at neutral $\mathrm{pH}$ followed by washing the column with 10 or 20 column volumes of TBS. The Flag-fused protein was eluted using $0.1 \mathrm{M}$ Glycine- $\mathrm{HCl}$ at $\mathrm{pH} 3.5$ and after elution, the $\mathrm{pH}$ was neutralized using $1 \mathrm{M}$ Tris ( $\mathrm{pH}$ 8.0). The purity and specificity of the eluted protein was determined using Silver staining and Western blotting respectively. The amount of protein was estimated using the BCA protein Assay Kit (Pierce).

In vitro cell proliferation assay. For growth experiments, cells were harvested by centrifugation and washed 3 times in Iscove's modified Dulbecco's medium with HEPES buffer supplemented with glutamine, antibiotics and $10 \mu \mathrm{g} / \mathrm{ml}$ of human transferrin (Sigma). Cells were seeded in 96-well tissue culture plates at a density of $5 \times 10^{4}$ cells $/ \mathrm{ml}(150 \mu 1 /$ well $)$ in the absence or presence of $10 \mathrm{ng} /$ well of purified pCD and different mutant pCD proteins in triplicate wells. After 5 days in culture, the proliferation was evaluated using Biotrak cell proliferation ELISA system (Amersham Pharmacia Biotech, Piscataway, NJ). Cells were incubated in BrdU-containing medium at $37^{\circ} \mathrm{C}$ for $2 \mathrm{~h}$, then fixed and incubated with blocking solution for $30 \mathrm{~min}$. Peroxidase-labelled anti-BrdU was added and incubated for $90 \mathrm{~min}$. After washing the wells 3 times, the chromogenic peroxidase substrate was added to each well and incubated for $30 \mathrm{~min}$. The optical density was measured at $450 \mathrm{~nm}$ using an SLT ELISA reader (Tecan, Research Triangle Park, NC). Cells cultivated in $10 \%$ FCS were taken as positive control and cells grown without FCS as negative control. 
Immunoprecipitation. The technique was performed using anti-Flag M2 affinity gel as described in the manufacturer's instructions (Sigma). Briefly, equal amounts of purified protein were mixed with proliferation assay media and incubated at $37^{\circ} \mathrm{C}$ for $0,24,48,72$ and $96 \mathrm{~h}$ respectively. At the end of each time interval, $10 \mu 1$ of equilibrated $3 \mathrm{x}$ Flag beads were added into the media and incubated at RT with gentle shaking for $2 \mathrm{~h}$. The beads were extensively washed and the Flag-fused protein was eluted using $100 \mu 1$ glycine$\mathrm{HCl}$ in tubes containing $10 \mu \mathrm{l}$ of $500 \mathrm{mM}$ Tris, $\mathrm{pH} 7.4$ and $1.5 \mathrm{M} \mathrm{NaCl}$. The supernatants were precipitated, the pellets were resuspended in Laemmli sample buffer and analyzed by Western blotting with anti-AP and anti-CD antibodies (Calbiochem, San Diego, CA).

Tumor cell growth in mice. Parental cells as well as the stable transfectants of various constructs were trypsinized, washed, centrifuged and resuspended in cold PBS. A total volume of $0.2 \mathrm{ml}$ of cell suspension containing $4 \times 10^{6}$ cells was injected through the tail vein in 5-6-week-old Balb/c athymic nude mice. Each group comprised of at least 5 mice. Eight weeks after cell injection, mice were euthanized by inhalation of $\mathrm{CO}_{2}$. Euthanasia was confirmed by pneumothorax. A complete necropsy was performed on all mice and the heart, lungs, kidney, liver, spleen and parts of the intestinal tract were removed and fixed in $10 \%$ buffered formalin. Fixed tissues were trimmed and paraffin-embedded for processing. The blocks were cut into $4-\mu \mathrm{m}$ sections and stained with hematoxylin and eosin for histopathological examination. In a different experiment, $1 \times 10^{7}$ parental as well as transfected HBL-100 and MDA-MB-231 cells were injected in mice through tail vein and checked for their survival after six weeks.

Statistical analysis. Student's unpaired t-test was used to calculate statistical differences between data sets. Significant difference was set at $\mathrm{P}<0.05$. Proliferation data were assessed by one-way analysis of variance (ANOVA), using SigmaSTAT software with Holm-Sidak method for multiple comparison $(\mathrm{P} \leq 0.05)$.

\section{Results}

Expression of $p C D$ and various mutants of $p C D$ in human breast cancer cell lines. Enzymatically active $\mathrm{CD}$ is not mitogenic, but its precursor form pCD acts as a mitogen. To decipher which region or activity of $\mathrm{pCD}$ confers mitogenicity, we designed and tested a series of mutants. The catalytic site of CD including two aspartic acid residues localized at positions 33 and 231, that are crucial for the CD enzymatic activity, were mutated and designated as $\mathrm{pCD}(33 \mathrm{~m})$ and $\mathrm{pCD}(231 \mathrm{~m})$ respectively. The two N-linked glycosylation sites at asparagine residues 70 and 199 were abrogated and named $\mathrm{pCD}(70 \mathrm{~m}), \mathrm{pCD}(199 \mathrm{~m})$ and $\mathrm{pCD}(70+199 \mathrm{~m})$. Previous studies from our laboratory demonstrated that synthetic AP induced mitogenic responses similar to those of intact $\mathrm{pCD}$ $(15,28)$. To explore the molecular basis of these results, $\mathrm{pCD}$ lacking its $\mathrm{AP}, \mathrm{pCD}(\triangle \mathrm{AP})$, and $\mathrm{pCD}$ with different amino acid mutations in the AP region were constructed and designated as $\mathrm{pCD}(\mathrm{APm} 1, \mathrm{APm} 2, \mathrm{APm} 3, \mathrm{APm} 4)$. The schematic representation of the various constructs is depicted in Fig. 1 and the


Figure 1. Schematic representation of pCD constructs used in this study. The full length pCD was cloned in p3XFlag-CMV vector. The $\mathrm{pCD}(\triangle \mathrm{AP})$ is the clone lacking the 44 amino-acid-long $\mathrm{AP}$ region. The $\mathrm{pCD}(33 \mathrm{~m})$ and $\mathrm{pCD}(231 \mathrm{~m})$ are the catalytically inactive pCD mutants. The $\mathrm{pCD}(70 \mathrm{~m})$ and $\mathrm{pCD}(199 \mathrm{~m})$ are the monoglycosylated mutants of $\mathrm{pCD}$ while $70+199 \mathrm{~m}$ is the non-glycosylated mutant of pCD.

different mutants of $\mathrm{pCD}$ with specific amino acid substitutions in AP region are listed in Fig. 2A(i). The selection of the site for mutation in AP region was based on the 3D model of pCD generated by Dr Michael Mares, IOCB, CAS, Prague (unpublished data).

These recombinant constructs were stably transfected into HBL-100 breast cell line, which lacks endogenous secretion of $\mathrm{pCD}$, to analyze the direct effect of these mutations. Control pCD, $\mathrm{pCD}(\triangle \mathrm{AP}), \mathrm{pCD}(33 \mathrm{~m})$ and $\mathrm{pCD}(231 \mathrm{~m})$ were also transfected into MDA-MB-231 breast cancer cell line that has inherent secretion of pCD. Expression of $\mathrm{pCD}$ and its various mutants from the stably transfected cells was analyzed on a Western blot probed with anti-AP and antiFlag antibodies [Fig. 2A(i) and B(i)]. Production of AP mutants in HBL-100 cells was confirmed using anti-Flag antibodies [Fig. 2A(i)].

Analysis of proteolytic activity of expressed $p C D$ and various mutants. Although, pCD is catalytically inactive, it is capable of acid-dependent autoactivation in vitro to yield catalytically active pseudo-cathepsin D (29). In case of HBL-100 clones, wild-type pCD, monoglycosylated and non-glycosylated 


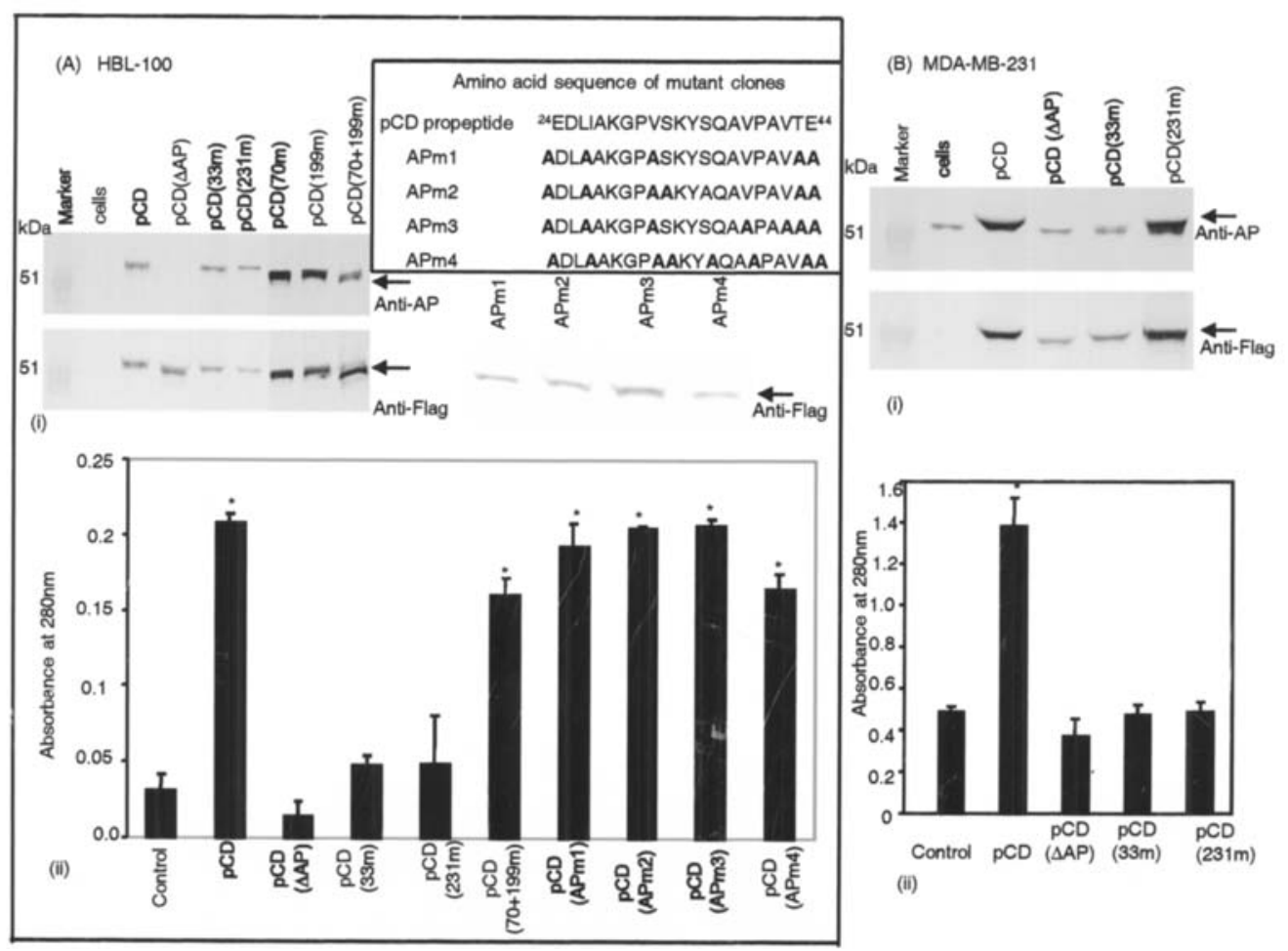

Figure 2. Analysis of expression and proteolytic activity of pCD and its mutants in (A) HBL-100 and (B) MDA-MB-231 cells. (i) Conditioned media from control and transfected cells were collected after 2 days and immunoblotted using anti-AP and anti-Flag antibodies. Amino acid mutations done in AP region of pCD are depicted in tabular form. Conditioned media of AP mutant constructs were analyzed by Western blotting using anti-Flag antibodies. (ii) Secreted pCD and its mutant proteins were analyzed for proteolytic activity using the hemoglobin degradation assay. Data represent the mean \pm SD of three independent experiments. ${ }^{*} \mathrm{P}<0.05$ versus the control (t-test)

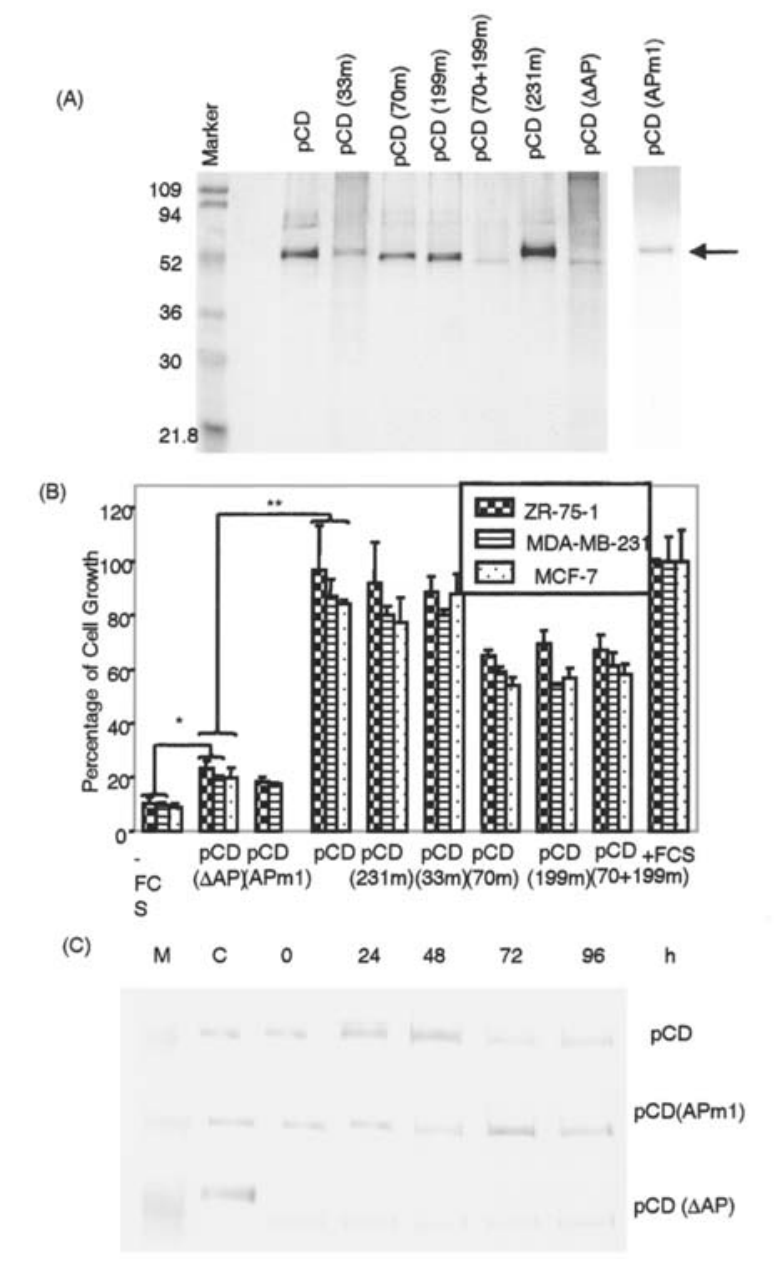

Figure 3. Effect of purified pCD and its mutant proteins on proliferation of different breast cancer cell lines. (A) Purified proteins were electrophoresed on SDS-PAGE and checked on silver stained gel. Arrow indicates the purified proteins. (B) Histogram of in vitro proliferation assay. Equal amount of purified $\mathrm{pCD}$ and its mutant proteins were used to evaluate the effect on proliferation of ZR-75-1, MDA-MB-231 and MCF-7 cells in serum-free conditions. The growth of cells in 10\% FCS was considered as $100 \%$ (positive control) and -FCS was taken as negative control. The percentage of cell growth is shown as mean \pm SD of three independent experiments performed in triplicate. The data were analyzed by ANOVA with $\mathrm{P}=0.05$. ${ }^{*}$ Significant with $\mathrm{P} \leq 0.05$ and ${ }^{* *}$ significant with $\mathrm{P} \leq 0.001$. (C) The stability of purified $\mathrm{pCD}, \mathrm{pCD}(\triangle \mathrm{AP})$ and $\mathrm{pCD}(\mathrm{APm} 1)$ was checked in the assay medium at the specified time intervals. The immunoprecipitated $\mathrm{pCD}$ was probed with anti-AP while the immunoprecipitated $\mathrm{pCD}(\triangle \mathrm{AP})$ and $\mathrm{pCD}(\mathrm{APm} 1)$ were probed with anti-CD antibody. ' $\mathrm{C}$ ' represents purified $\mathrm{pCD}$ as a positive control for immunoblotting.

mutants of pCD displayed proteolytic activity at $\mathrm{pH} 3.5$ in contrast to $\mathrm{pCD}(33 \mathrm{~m})$ and $\mathrm{pCD}(231 \mathrm{~m})$ mutants. In addition, $\mathrm{pCD}(\triangle \mathrm{AP})$ was found to be catalytically inactive while the various AP mutant clones (APm1, APm2, APm3 and APm4) were proteolytically active [Fig. 2A(ii)]. pCD and its mutants derived from the supernatant of MDA-MB-231 stable clones also displayed proteolytic activity in a similar fashion [Fig. 2B(ii)]. The observed proteolytic activity in MDA-MB-231 cells is explained due to the inherent secretion of $\mathrm{pCD}$ in its conditioned media.

Increased proliferation of breast cancer cells in the presence of $A P$. In order to assess the effect of various mutations of $\mathrm{pCD}$ on proliferation of breast cancer cells, expressed $\mathrm{pCD}$ 
(A)

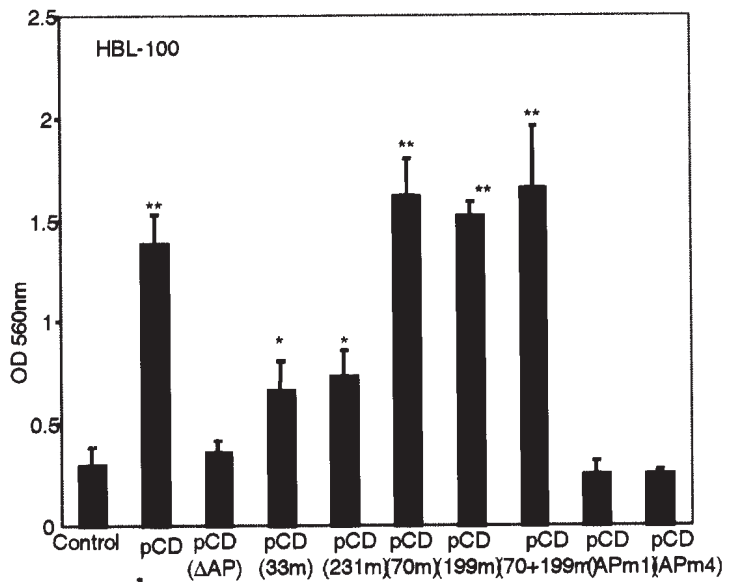

(B)

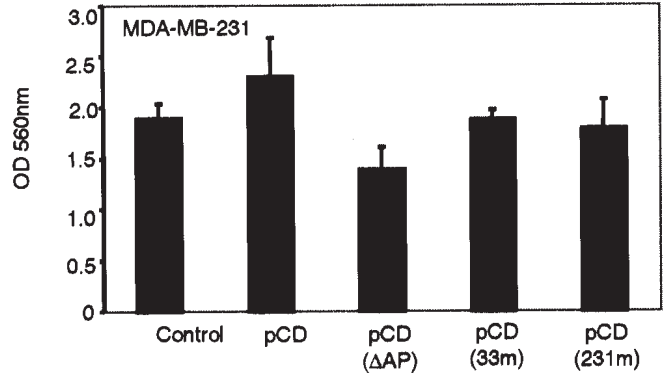

Figure 4. Determination of invasive potential of $\mathrm{pCD}$ and mutant transfected in (A) HBL-100 and (B) MDA-MB-231 cells. The cells $\left(3 \times 10^{5}\right)$ were incubated on the top of the Matrigel-coated filters and the extent of cell invasion was measured after staining invasive cells by colorimetric reading at $560 \mathrm{~nm}$. The experiment was repeated thrice and the data represent the mean $\pm \mathrm{SD}$ of three independent experiments. ${ }^{*} \mathrm{P}<0.05,{ }^{* *} \mathrm{P}<0.001$ versus mean of control cells (t-test)

and its mutants were affinity purified and analyzed on a silverstained gel (Fig. 3A). The proliferation of ZR-75-1, MCF-7 and MDA-MB-231 cells after exogenous addition of purified proteins was determined using incorporation of BrdU in actively dividing cells. Purified $\mathrm{pCD}$ along with $\mathrm{pCD}(33 \mathrm{~m})$ and $\mathrm{pCD}(231 \mathrm{~m})$ elicited an enhanced proliferation in these cell lines (Fig. 3B). Additionally, purified pCD(70m), pCD(199m) and $\mathrm{pCD}(70+199 \mathrm{~m})$ glycomutants were able to show increased proliferation but the effect was $\sim 20 \%$ less $(\mathrm{P} \leq 0.01)$ when compared to proliferation obtained with wild-type pCD. In contrast, $\mathrm{pCD}(\triangle \mathrm{AP})$ and $\mathrm{pCD}(\mathrm{APm} 1)$ failed to induce proliferation in any of these cell lines. Further, the stability of the purified proteins $[\mathrm{pCD}, \mathrm{pCD}(\triangle \mathrm{AP})$ and $\mathrm{pCD}(\mathrm{APm} 1)]$ was verified under the assay conditions for the duration of the experiment and were found to be stable (Fig. 3C).

Presence of the intact propeptide region of $p C D$ imparts invasiveness to $H B L-100$ cells. For further insight into the invasive potential of cells due to expression of $\mathrm{pCD}$ and its mutants, the in vitro invasive model, Matrigel, was used. The control HBL-100 cells with no inherent secretion of pCD did not show any invasion while a significant increase in invasion was evident when these cells were transfected with either $\mathrm{pCD}$ or its various mutant forms i.e. $\mathrm{pCD}(33 \mathrm{~m}), \mathrm{pCD}(231 \mathrm{~m})$, $\mathrm{pCD}(70 \mathrm{~m}), \mathrm{pCD}(199 \mathrm{~m})$ and $\mathrm{pCD}(70+199 \mathrm{~m})$. In contrast, HBL-100 cells with $\mathrm{pCD}(\triangle \mathrm{AP}), \mathrm{pCD}(\mathrm{APm} 1)$ and $\mathrm{pCD}(\mathrm{APm} 4)$ showed no enhancement of invasion (Fig. 4A). Similar
Table I. Production of experimental metastasis by transfectants of pCD and its various mutants. ${ }^{\mathrm{a}}$

\begin{tabular}{|c|c|c|}
\hline Cell line & $\begin{array}{c}\text { Incidence } \\
\text { (Macroscopic } \\
\text { lung colonies) } \\
4 \times 10^{6} \text { cells }\end{array}$ & $\begin{array}{l}\text { Survival } \\
1 \times 10^{7} \text { cells }\end{array}$ \\
\hline HBL-100 control cells & $1 / 10$ & $6 / 6$ \\
\hline HBL-100 with pCD & $4 / 10$ & $3 / 6$ \\
\hline HBL-100 with pCD(70+199m) & $5 / 10$ & $3 / 6$ \\
\hline HBL-100 with $\mathrm{pCD}(\triangle \mathrm{AP})$ & $0 / 8$ & $5 / 5$ \\
\hline HB1-100 with pCD(APm1) & $2 / 10$ & $6 / 6$ \\
\hline MDA-MB-231 control cells & $10 / 10$ & $0 / 9$ \\
\hline MDA-MB-231 with pCD & $9 / 9$ & $0 / 8$ \\
\hline MDA-MB-231 with $\mathrm{pCD}(\Delta \mathrm{AP})$ & $1 / 5$ & $5 / 7$ \\
\hline MDA-MB-231 with pCD(231m) & $4 / 5$ & $0 / 6$ \\
\hline
\end{tabular}

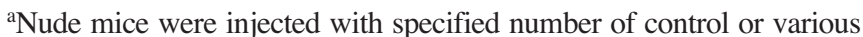
mutants of pCD transfected cells via tail vein. Mice were euthanized after 8 weeks and metastatic foci were checked on lung surface macroscopically. Number of mice with metastasis/number of mice injected.

results were obtained with HBL-100 cells transfected with $\mathrm{pCD}(\mathrm{APm} 2)$ and $\mathrm{pCD}(\mathrm{APm} 3)$ (data not shown). MDAMB-231 cells transfected with pCD and its mutants also showed an increase in invasion as compared to control cells but the difference was not significant due to high levels of inherent secretion of pCD by these cells. The present results together with our earlier studies strongly support our hypothesis that the intact $\mathrm{C}$-terminal $\mathrm{AP}$ region of $\mathrm{pCD}$ is responsible for enhancement in invasive potential of HBL-100 stable transfectants.

The presence of propeptide of $p C D$ determines the tumorigenicity of human breast cancer cell lines in nude mice. For the in vivo analysis, $4 \times 10^{6}$ cells were injected and analyzed for lung metastases by control HBL-100, MDA-MB-231 and their various transfected cells after 8 weeks. An increase in the incidence of lung metastases was observed in mice injected with cells transfected with wild-type pCD and its glycosylation and catalytic mutants while the recipient animals of $\mathrm{pCD}(\triangle \mathrm{AP})$ and $\mathrm{pCD}(\mathrm{APm} 1)$ transfected cells showed no increase in lung metastases (Table I). Further, microscopic analysis of histological slides of control HBL-100 cells showed very few areas with tumor cells infiltration around capillaries while the HBL-100 cells with pCD and $\mathrm{pCD}(70+199 \mathrm{~m})$ showed large nests of tumor cells surrounded by numerous inflammatory cells. Conversely, the HBL-100 cells with $\mathrm{pCD}(\triangle \mathrm{AP})$ and $\mathrm{pCD}(\mathrm{APm} 1)$ occasionally showed few tumor cells around large bronchioles with minimal infiltration and no necrosis. In the case of MDA-MB-231 cells, the control cells showed large tumor masses with marked tissue infiltration, inflammation and tissue necrosis. Similar nests of tumor cells with moderate infiltration and necrosis were observed with MDA-MB-231 

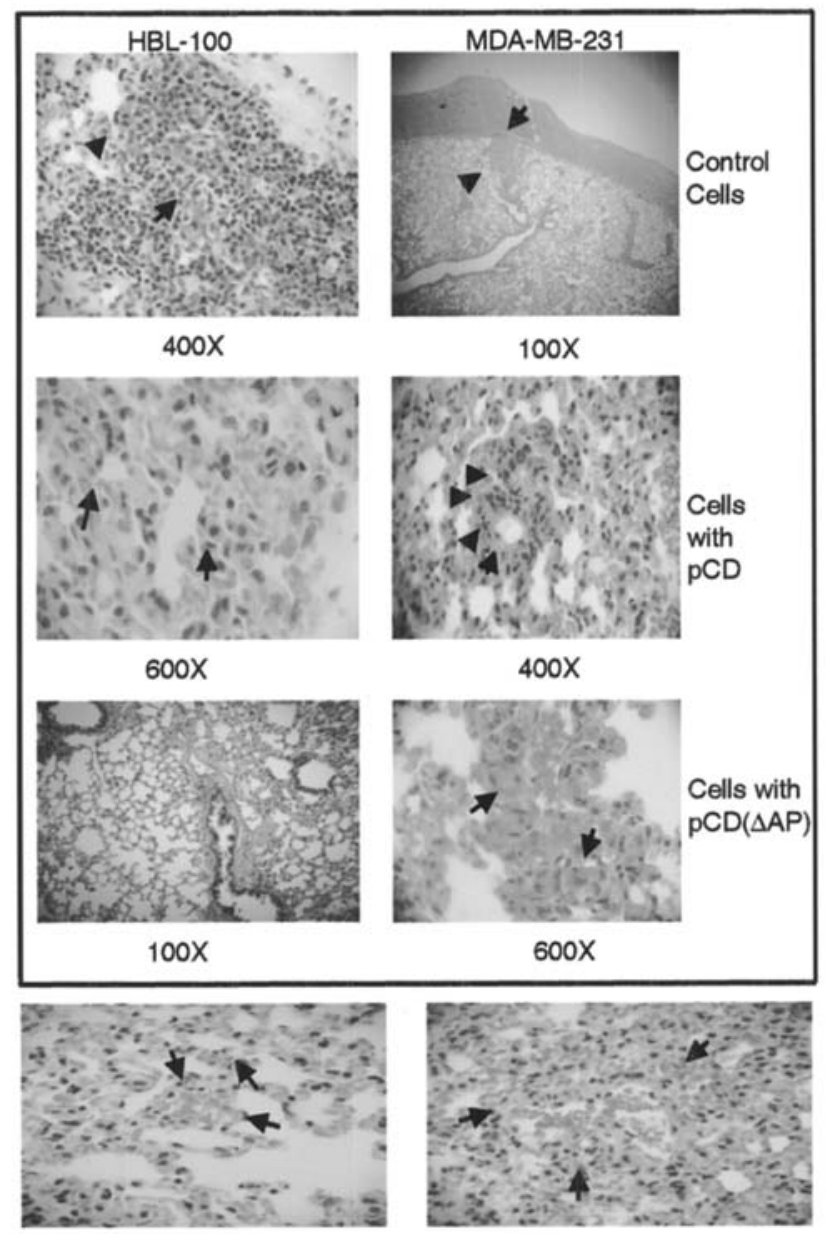

MDA-231 with $\mathrm{pCD}(231 \mathrm{~m}) 400 \mathrm{X} \mathrm{HBL}-100$ with $\mathrm{pCD}(70+199 \mathrm{~m}) 400 \mathrm{X}$

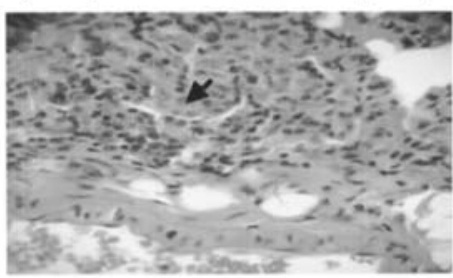

$\mathrm{HBL}-100$ with $\mathrm{pCD}(\mathrm{APm} 1) 400 \mathrm{X}$

Figure 5. Effect of presence of propeptide of pCD on lung colonization of HBL-100 and MDA-MB-231 cells in vivo. Representative histology slide of hematoxylin-eosin stained section of lung tissue from nude mice injected with control HBL-100 or MDA-MB-231 cells (right), stably transfected with full pCD construct (middle) and transfected with pCD( $\triangle \mathrm{AP})$ (left) is shown. Representative slide of nude mice injected with MDA-MB-231 cells transfected with $\mathrm{pCD}(231 \mathrm{~m})$ and HBL-100 cells transfected with $\mathrm{pCD}(70+199 \mathrm{~m})$ and $\mathrm{pCD}(\mathrm{APm} 1)$ is also shown. Tumor cells are shown with an arrow and original magnification is specified.

cells harbouring $\mathrm{pCD}$ and $\mathrm{pCD}(231 \mathrm{~m})$ while the cells harbouring $\mathrm{pCD}(\triangle \mathrm{AP})$ showed isolated tumor cells with minimalto-moderate infiltration and tissue necrosis (Fig. 5). In a different experiment, mice were injected with $1 \times 10^{7}$ parental as well as transfected HBL-100 and MDA-MB-231 cells through tail vein and checked for their survival after six weeks. Our data clearly demonstrated that recipient mice containing cells transfected with $\mathrm{pCD}(\triangle \mathrm{AP})$ and $\mathrm{pCD}(\mathrm{APm} 1)$ had a better survival rate as compared to recipient animals with cells transfected with wild-type pCD or catalytic or glycosylation mutants.

\section{Discussion}

In the present study, we have assessed the various structural/ functional features of $\mathrm{pCD}$ that might be responsible for its mitogenic activity. Earlier studies searched for the moieties involved for this activity independently $(30,31)$. However, this is the first comprehensive study where all the features of pCD have been checked simultaneously on human breast cancer cell lines. For this purpose, pCD and its various mutant constructs were transfected and expressed in HBL-100 (no inherent secretion of pCD) and MDA-MB-231 (possessing endogenous secretion of $\mathrm{pCD}$ ) cell lines to determine the direct effect of mutant constructs on mitogenic activity of pCD.

Proteolytic activity of proteases is generally assumed to play role in cancer development as it favours escape of cancer cells from the primary site by degradation of extra-cellular matrices and basement membrane (32). Cathepsins L and B have been shown to play role in matrix degradation and cell invasion $(33,34)$. However, cathepsin D requires a more acidic $\mathrm{pH}$ to be proteolytically active as compared to cysteine lysosomal enzymes like cathepsin (B and L). Moreover, earlier studies have showed that the mitogenic activity of pCD was not connected to its proteolytic activity as the study showed the proliferative effect of $\mathrm{pCD}$ even in the presence of pepstatin A (an inhibitor of CD proteolytic activity) (30). Later, by transfection of catalytically-inactive (Asn 231 mutant) human $\mathrm{pCD}$ in rat tumor cells, it was shown that mitogenic activity does not require the pCD catalytic activity (31). In the present study, we generated catalytic mutants at both the 33 and 231 sites and found efficient stable expression of proteins in the transfected cells. The expressed proteins were found to be proteolytically inactive and exogenous addition of the purified proteins showed enhanced proliferation of breast cancer cell lines. The stable transfectants of these mutant proteins also showed an increased invasion in vitro and increase in tumorigenic potential in vivo. Taken together, we can conclusively state that the proteolytic activity is not necessary for the cancerogenic properties of pCD.

The next structural feature that gained our attention was the sugar moiety particularly due to the possible interaction with M6P receptors. Some studies suggested that pCD acts as a ligand by interaction of its M6P moieties with the M6P/insulin-like growth factor-2 receptor (35). To decipher the possibility of involvement of M6P tag or the sugar moiety of pCD on the tumor growth, mono- and non-glycosylation mutants of pCD were constructed and stably transfected in HBL-100 cell line. The glycosylation mutants of pCD were readily expressed and were proteolytically active, assuring the proper folding of these proteins. Exogenous addition of these purified proteins on breast cancer cell lines exhibited an enhancement in proliferation, but the level was $20 \%$ less as compared to wild-type pCD protein. This result is in line with our previous observation that removal of oligosaccharide side chains slightly lowers the pCD activity in proliferation assay (30). The stable transfectants of these mutant proteins showed increased invasion in matrigel assay and an increase in lung colonization potential when injected in nude mice. These results indicate that the sugar moieties are not involved in the tumor promoting effect of $\mathrm{pCD}$. 
The other structural feature of $\mathrm{pCD}$ is the presence of AP region. In our earlier studies, we observed that $\mathrm{pCD}$ and its synthetic AP displayed similar proliferative effect on various cancer cell lines $(15,28)$. Later, it was also shown that the mitogenic activity of pCD was abolished using polyclonal antibodies raised against the synthetic AP (36). A more detailed study revealed that the C-terminal region of AP encompassing the 27-44 aa residues attributed to this activity (36). However, the direct effect of AP alone and in conjunction with other structural and functional features of pCD has never been studied. Therefore, in this study we constructed the AP deletion mutant as well as various mutants of AP harboring mutations at the $\mathrm{C}$-terminal region. The $\mathrm{pCD}(\triangle \mathrm{AP})$ construct was stably expressed by both HBL-100 and MDAMB-231 cells. Expression of a similar construct was earlier reported in human kidney 293 cells and CHO-L76 cells, to study the role of propeptide in expression of CD (26). The expression level of $\mathrm{pCD}(\triangle \mathrm{AP})$ was comparable to that of pCD in HBL-100 cells, whereas in MDA-MB-231 cells its expression was lower than the expressed pCD. Expressed $\mathrm{pCD}(\triangle \mathrm{AP})$ mutant protein was found to be proteolytically inactive in the in vitro proteolytic activity assay. Improper folding of expressed protein might be responsible for this lack of catalytic activity as the folding process was shown to be templated by AP (37). This hypothesis was further confirmed by expression of other AP region mutants, as they were found to be proteolytically active, indicating the correct folding of mutant pCD in the presence of AP region. However, exogenous addition of purified AP mutant proteins on breast cancer cell lines did not display any enhancement in proliferation nor did the stable transfectants of $\mathrm{pCD}(\triangle \mathrm{AP})$ and $\mathrm{pCD}(\mathrm{APm} 1-4)$ show any increase in invasion in vitro. The importance of AP was further strengthened by our in vivo studies as the recipients of stable transfectants of these mutants did not show any increase in incidence of metastasis in contrast to the transfectants of wild-type pCD or catalytic or glycosylation mutants of pCD.

In conclusion, our results demonstrate that expression and secretion of $\mathrm{pCD}$ achieved by transfection of $\mathrm{pCD}$ construct in HBL-100 cells increased the metastatic potential of this cell line. We further provide conclusive evidence that AP region is essential for the mitogenic activity of $\mathrm{pCD}$ and the whole intact region from 27-44 amino acids of AP is required for this function. This study opens a new prospective for developing therapeutic strategies for breast cancer by specifically targeting the interaction of AP with tumor cells.

\section{Acknowledgements}

The work was supported by a research grant from the NIHIR01 CA82 159-01A2, USA. The authors wish to thank Dr John M. Chirgwin for critically reading the manuscript.

\section{References}

1. Stitziel NO, Brenton GM, Liang J and Westbrook CA: Membraneassociated and secreted genes in breast cancer. Cancer Res 64: 8682-8687, 2004.

2. Nomura $T$ and Katumuna $N$ : Involvement of cathepsins in the invasion, metastasis and proliferation of cancer cells. J Med Invest 52: 1-9, 2005.
3. Rochefort H, Capony F, Garcia M, Cavailles V, Freiss G, Chambon M, Morisset M and Vignon F: Estrogen-induced lysosomal proteases secreted by breast cancer cells: a role in carcinogenesis? J Cell Biochem 35: 17-29, 1987.

4. Kane SE and Gottesman MM: The role of cathepsin L in malignant transformation. Semin Cancer Biol 1: 127-136, 1990

5. Sloane BF: Cathepsin B and cystatins: evidence for a role in cancer progression. Semin Cancer Biol 1: 137-152, 1990.

6. Leto G, Tumminello FM, Crescimanno M, Flandina C and Gebbia N: Cathepsin D expression levels in non-gynecological solid tumors: clinical and therapeutic implications. Clin Exp Metastasis 21: 91-106, 2004.

7. Rochefort H: Cathepsin D in breast cancer: a tissue marker associated with metastasis. Eur J Cancer 28: 1780-1783, 1992.

8. Ferrandina G, Scambia G, Bardelli F, Benedetti Panici P, Mancuso S and Messori A: Relationship between cathepsin-D content and disease-free survival in node-negative breast cancer patients: a meta-analysis. Br J Cancer 76: 661-666, 1997.

9. Foekens JA, Look MP, Bolt-de Vries J, Meijer-van Gelder ME, van Putten WL and Klijn JG: Cathepsin-D in primary breast cancer: prognostic evaluation involving 2810 patients. Br J Cancer 79: 300-307, 1997.

10. Brouillet JP, Dufour F, Lemamy G, Garcia M, Schlup N, Greiner J, Mani JC and Rochefort H: Increased cathepsin D level in the serum of patients with metastatic breast carcinoma detected with a specific pro-cathepsin D immunoassay. Cancer 79: 2132-2136, 1997.

11. Orlowski M: Pituitary endopeptidases. Mol Cell Biochem 52: 49-74, 1983

12. Mohamadzadeh M, Mohamadzadeh H, Brammer M, Sestak K and Luftig RB: Identification of proteases employed by dendritic cells in the processing of protein purified derivative (PPD). $J$ Immune Based Ther Vaccines 2: 8, 2004.

13. Bidere N, Lorenzo HK, Carmona S, Laforge M, Harper F, Dumont $\mathrm{C}$ and Senik A: Cathepsin D triggers Bax activation, resulting in selective apoptosis-inducing factor (AIF) relocation in $\mathrm{T}$ lymphocytes entering the early commitment phase to apoptosis. J Biol Chem 278: 31401-31411, 2003.

14. Stewart AJ, Piggott NH, May FEB and Westley BR: Mitogenic activity of procathepsin $\mathrm{D}$ purified from conditioned medium of breast-cancer cells by affinity chromatography on pepstatinyl agarose. Int J Cancer 57: 715-718, 1994.

15. Vetvicka V, Vetvickova J and Fusek M: Effect of human cathepsin D on proliferation of human cell lines. Cancer Lett 79: 131-135, 1994.

16. Berchem G, Glondu M, Gleizes M, Brouillet JP, Vignon F, Garcia $M$ and Liaduet-Coopman E: Cathepsin-D affects multiple tumor progression steps in vivo: proliferation, angiogenesis and apoptosis. Oncogene 21: 5951-5955, 2002.

17. Garcia M, Dercoq D, Pujol P and Rochefort H: Overexpression of transfected cathepsin D in transformed cells increases their malignant phenotype and metastatic potency. Oncogene 5: 1809-1814, 1990.

18. Glondu M, Liaudet-Coopman E, Derocq D, Platet N, Rochefort H and Garcia M: Down-regulation of cathepsin-D expression by antisense gene transfer inhibits tumor growth and experimental lung metastasis of human breast cancer cells. Oncogene 21: 5127-5134, 2002.

19. Vashishta A, Ohri SS, Proctor M, Fusek M and Vetvicka V: Ribozyme-targeting procathepsin D and its effect on invasion and growth of breast cancer cells: An implication in breast cancer therapy. Int J Oncol 30: 1223-1230, 2007.

20. Ohri SS, Vashishta A, Proctor M, Fusek M and Vetvicka V: Depletion of procathepsin D gene expression by RNA interference - a potential therapeutic target for breast cancer. Cancer Biol Ther 6: e1-e7, 2007.

21. Kornfeld S: Lysosomal enzyme targeting. Biochem Soc Trans 18: 367-374, 1990.

22. Richo G and Conner GE: Structural requirements of procathepsin D activation and maturation. J Biol Chem 269: 14806-14812, 1994.

23. Vetvicka V, Vetvickova J, Hilgert I, Voburka Z and Fusek M: Analysis of the interaction of procathepsin $\mathrm{D}$ activation peptide with breast cancer cells. Int J Cancer 73: 403-409, 1997.

24. Benes P, Vashishta A, Saraswat-Ohri S, Fusek M, Pospisilova S, Tichy B and Vetvicka V: Effect of procathepsin D activation peptide on gene expression of breast cancer cells. Cancer Lett 239: 46-54, 2006. 
25. Faust PL, Kornfeld S and Chirgwin JM: Cloning and sequence analysis of cDNA for human cathepsin D. Proc Natl Acad Sci USA 82: 4910-4914, 1985.

26. Fortenberry SC and Chirgwin JM: The propeptide is nonessential for the expression of human cathepsin D. J Biol Chem 270: 9778-9782, 1995

27. Vetvicka V, Vetvickova J and Benes P: Role of enzymatically inactive procathepsin D in lung cancer. Anticancer Res 24: 2739-2743, 2004.

28. Vetvicka V, Vetvickova J and Fusek M: Effect of procathepsin D and its activation peptide on prostate cancer cells. Cancer Lett 129: 55-59, 1998.

29. Conner GE: Isolation of procathepsin D from cathepsin D by pepstatin affinity chromatography. Autocatalytic proteolysis of the zymogen form of the enzyme. Biochem J 263: 601-604, 1989.

30. Fusek M and Vetvicka V: Mitogenic function of human procathepsin D: the role of the propeptide. Biochem J 303: 775-780, 1994.

31. Glondu M, Coopman P, Laurent-Matha V, Garcia M, Rochefort H and Liaudet Coopman E: A mutated cathepsin-D devoid of its catalytic activity stimulates the growth of cancer cells. Oncogene 20: 6920-6929, 2001.
32. Liotta LA, Rao CN and Wewer UM: Biochemical interactions of tumor cells with the basement membrane. Ann Rev Biochem 55: 1037-1057, 1986.

33. Sloane BF, Rozhin J, Hatfield JS, Crissman JD and Honn KV: Plasma membrane-associated cysteine proteinases in human and animal tumors. Exp Cell Biol 55: 209-224, 1987.

34. Qian F, Bajkowski AS, Steiner DF, Chan SJ and Frankfater A: Expression of five cathepsins in murine melanomas of varying metastatic potential and normal tissues. Cancer Res 49: 4870-4875, 1989.

35. De Leon DD, Terry C, Asmerom Y and Nissley P: Insulin-like growth factor II modulates the routing of cathepsin D in MCF-7 breast cancer cells. Endocrinology 137: 1851-1859, 1996.

36. Vetvicka V, Vetvickova J and Fusek M: Anti-human procathepsin D activation peptide antibodies inhibit breast cancer development. Breast Cancer Res Treat 57: 261-269, 1999.

37. Conner GE: The role of the cathepsin D propeptide in sorting to the lysosome. J Biol Chem 267: 21738-21745, 1992. 